PRODUCTION

ENGINEERING

ARCHIVES
2016, Vol. 10, No 1, pp 38-41

ISSN 2353-5156

ISSN 2353-7779 (print version)

(online version)

Article history: Received: 07.02.2016

\title{
Technical aspects of casting and their effect on the quality of Remanium CSe dental alloys
}

\author{
Dorota Klimecka-Tatar ${ }^{1}$, Klaudia Radomska², Grażyna Pawłowska² \\ ${ }^{1}$ Institute of Production Engineering, Faculty of Management, Czestochowa University of Technology, Armii Krajowej 19B, 42-201 \\ Czestochowa, Poland, +48 343250 399, e-mail: klimt@wp.pcz.pl \\ ${ }^{2}$ Faculty of Production Engineering and Materials Technology, Department of Chemistry, Czestochowa University of Technology, Armii \\ Krajowej 19, 42-201 Czestochowa, Poland, +48 343250 604, e-mail: pawlow@wp.pcz.pl
}

\begin{abstract}
The study concerns on investigation of Remanium CSE alloy, one of the dental alloys used in metal-ceramic connection preparation. The alloys based on Ni-Cr-Mo are widely used in dental engineering because of their high mechanical, tribological properties as well as high corrosion resistance. The tested alloy has been processed in three ways - it has been remelted and then casted using three technologiescommonly used in dental laboratories, i.e. with: oxy-acetylene burner (1), induction furnace (2) and Volts arc (3). The aim of the study was to evaluate the effect of the melting and casting techniques on the mechanical strength and stereometric surface properties. The results revealed that the quality of Remanium CSe dental alloys significantly depend on the method of the material processing.
\end{abstract}

Key words: casting alloy, quality, surface roughness

\section{Introduction}

In prosthetic treatment, beneficial effects are achieved through proper selection of engineering materials with simultaneous control of technical procedures in prosthetic constructions preparation. For long-term use of dental restorations the materials should have satisfactory mechanical properties, strength and aesthetic (MAJEWSKI S., PRYLIŃSKI M. 2013; SCHMIDSEDER J. 2011; MARCINIAK J. 2003).

The formation of metallic prosthetic constructions are carried out by classical casting. The most popular methods include the use of oxygen-acetylene burner, and an induction furnace. Casting quality, especially when using oxygen-acetylene burner, depends on many external variable factors. Inter alia, on the quali- ty of the material highly affect the use of nonprotective atmosphere in the process - only in an induction furnace is it capable of being applied. The least frequently used technique is casting method Volta arc (KLIMECKA-TATAR D., RADOMSKA K., JAGIELSKAWIADEREK K. 2014; RADOMSKA K., PAWŁOWSKA G., KLIMECKA-TATAR D. 2013). A number of research works (K. RADOMSKA, G. PAWŁOWSKA, D. KLIMECKA-TATAR 2015a,b,c,d) indicate the relationship between production methods, structural/chemical composition of based alloys and the quality of prosthetic constructions. Furthermore, the processing method affects the surface development and consequently on the contact area between the material and the wall of bacterial cells contained in body fluids in the patient's Mouth (HILTBERT L.R., BAGGE-RAVN D., KOLD J., GRAM L 2013; TAYLOR R., MARYAN C., 
VERRRAN J. 1998; SZYMAŃSKI W. 2008; KAWAI K., URANO M., EBISU S. 2000; DELIGIANNI D., KATSALA N., LAdAs S., Sotiropoulou D., AMEdeE J., MISSIRLIS Y.F. 2001). The surface roughness is a parameter that affects the wettability of the surface which, in turn, promotes the deposition of bacteria. Colonization of the material by bacteria can be a source of infection and constitute an obstacle to the proper functioning of prosthetic constructions. According to Bollena and Quiryena research (BOLLEN CM., LAMBRECHTS P., QUIRYNEN M., 1997) the arithmetic average of absolute values $R a=200 \mathrm{~nm}$ is a threshold value and below it a significant reduction of bacteria number on the surface of the prosthesis is observed.

Previous studies of the team conducted on this group of dental alloys are related to their corrosion resistance. The aim of this study was to evaluate the effect of the melting/casting method on the mechanical strength of the dental alloy based on Ni-Cr-Mo and also the estimation of the quality surface based on the selected roughness parameters.

\section{Experimental}

\subsection{Material}

The material of investigation was Remanium CSe casting alloy with the chemical formula $\mathrm{Ni}_{61} \mathrm{Cr}_{26} \mathrm{Moo}_{11} \mathrm{Si}_{1,5}$ (the subscripts denote percentages by mass) with the residual content of: $\mathrm{Fe}, \mathrm{Co}, \mathrm{Al}$ and Ce. Metallic material were melt casted using: oxyacetylene burner, induction furnace and Volta arc.

Table 1. Identification and characterization samples according to technologies of melting/casting

\begin{tabular}{|c|c|}
\hline $\begin{array}{c}\text { Sample symbol } \\
\text { (Remanium CSe } \\
\text { dental alloy) }\end{array}$ & $\begin{array}{c}\text { The selected method } \\
\text { of melting/casting }\end{array}$ \\
\hline$(1)$ & $\begin{array}{c}\text { oxy - acetylene burner } \\
\text { (ceramic crucible, air atmosphere) }\end{array}$ \\
\hline$(2)$ & $\begin{array}{c}\text { induction furnace } \\
\text { (ceramic crucible, air atmosphere) }\end{array}$ \\
\hline$(3)$ & $\begin{array}{c}\text { Volta arc } \\
\text { (ceramic crucible, air atmosphere, } \\
\text { voltage 220V) }\end{array}$ \\
\hline
\end{tabular}

Source: own study

Melted dental alloy was introduced into the previously prepared molds, the shape of a disc with dimension $\varnothing=10 \mathrm{~mm}, h=5 \mathrm{~mm}$. The samples were made using three methods of melting/casting and determined as (1), (2) and (3) (Tab. 1). In order to standardize the surface of all the samples the surface was subjected to grinding aqueous paper ending gradation equal to 4000 to obtain the proper condition of their surface.

\subsection{Methodology of research}

Surface roughness is a characteristic of the solid surface and is recognizable optical or mechanical perceptible surface irregularities, not impacting on the shape. This parameter has a decisive influence on the functional properties of the final product.

The results of the surface roughness analysis of Remanium CSe casting alloy with the chemical formula $\mathrm{Ni}_{61} \mathrm{Cr}_{26} \mathrm{Mo}_{11} \mathrm{Si}_{1,5}$ are presented below. The roughness studies were conducted with contact profilometer (Taylor Hobson), section $4 \mathrm{~mm}$ for each sample. During the measurement the surface roughness profiles were recorded and outlined the Abbott curve, surface share of peaks and distribution of their size and the parameter values including stereometric parameter: $R a, R z$ and $R t$ (RADOMSKA K., PawŁowska G., Klimecka-Tatar D. 2015b). To compare the quality of the casted material in terms of different melting/casting methods the mechanical properties were evaluated by Vickers hardness.

\section{Results and discussion}

In Table 2 and Fig. 1 the results of roughness measurements of $\mathrm{Ni}_{61} \mathrm{Cr}_{26} \mathrm{Mo}_{11} \mathrm{Si}_{1,5}$ alloy are presented - in this study numerical values of parameters: $R a, R z$ and $R t$ were assigned.

Table 2. The surface profiles' selected parameters of $\mathrm{Ni}_{61} \mathrm{Cr}_{26} \mathrm{Mo11}_{11} \mathrm{Si}_{1,5}$ alloy

\begin{tabular}{|c|c|c|c|}
\hline Parameters & \multirow{2}{*}{ Ra, $\boldsymbol{\mu m}$} & $\mathbf{R} \mathbf{m}, \boldsymbol{\mu m}$ & $\mathbf{R z}, \boldsymbol{\mu m}$ \\
\cline { 1 - 3 } Sample & $0,01 \pm 0,02$ & $1,03 \pm 0,09$ & $0,64 \pm 0,02$ \\
\hline$(1)$ & $0,05 \pm 0,00$ & $0,48 \pm 0,09$ & $0,42 \pm 0,11$ \\
\hline$(2)$ & $0,11 \pm 0,03$ & $1,01 \pm 0,05$ & $0,83 \pm 0,01$ \\
\hline
\end{tabular}

Source: own study

It was observed that all tested samples obtained using three methods of melting/casting are characterized by low surface roughness parameters $R a<200 \mathrm{~nm}$, 
which according to the Bollena et al. study (BOLLEN CM, LAMBRECHTS P, QUIRYNEN M. 1997) is a satisfactory value. However, the samples are recognized by different values of roughness parameters which is dependent on the processing technology (Fig. 1).

a)

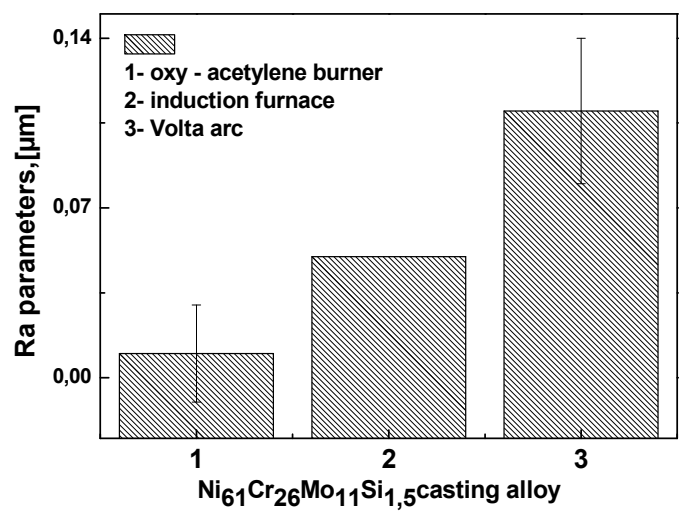

b)

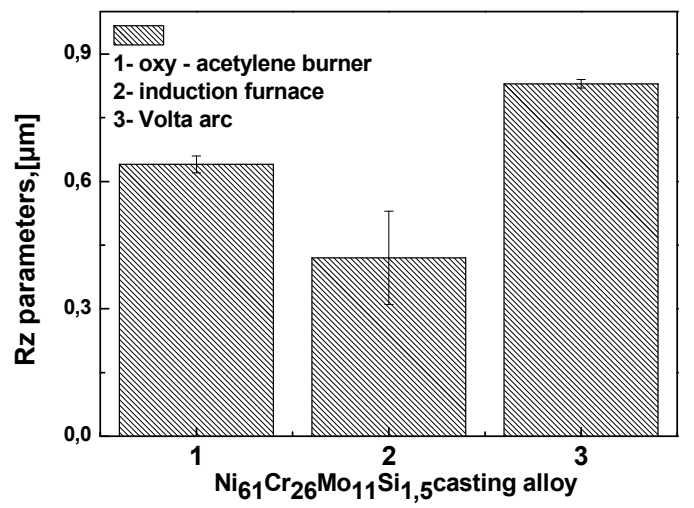

c)

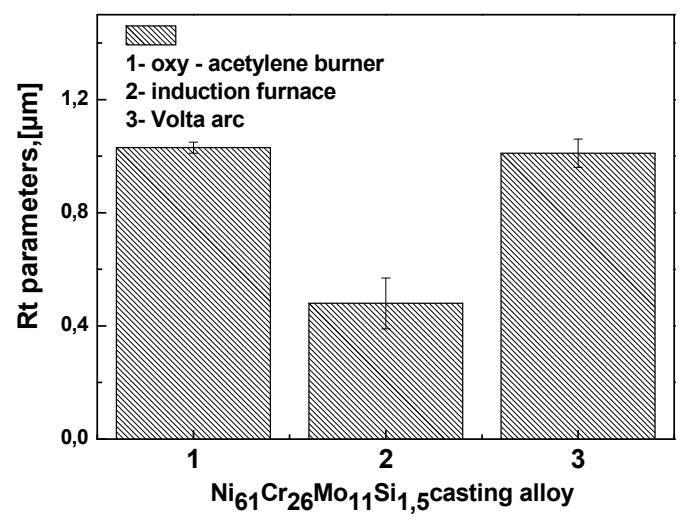

Fig.1. The comparison of the selected roughness parameters of $\mathrm{Ni}_{61} \mathrm{Cr}_{26} \mathrm{Mo}_{11} \mathrm{Si}_{1,5}$ casting alloy with respect to different meltSource: own study
Although all samples had been subjected to the same final treatment (mechanical polishing) their surfaces are defected to varying degrees - taking into account all the roughness parameters, the smoothest surface obtained was done so by the materials made in an induction furnace (2) (Fig. 1b). The method using Volta arch, as expected, had the most affects on the growth of roughness - in comparison to other samples (Fig.1c).

For registered profile the curve of vertices share and the verticle size distribution curve and The Abbott curve (bearing area curve) (Fig.2) has also been determined. Surface share of the vertices and their distribution indicates the smallest density of peaks for the sample (2) (Fig.2b).

a)

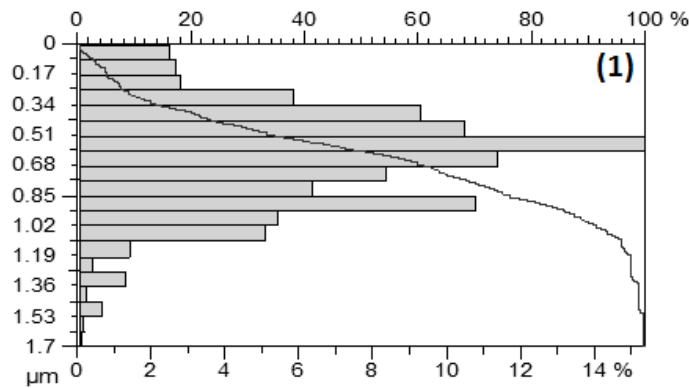

b)

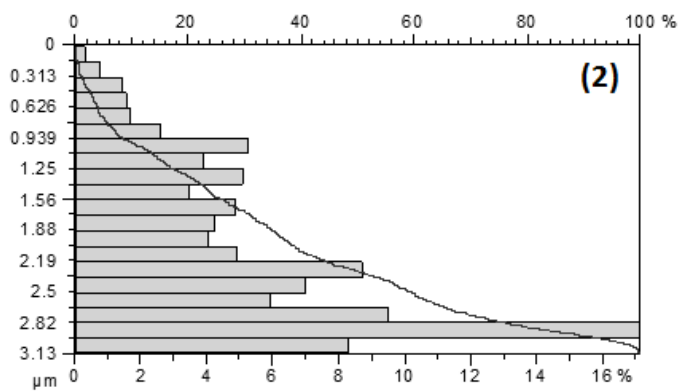

c)

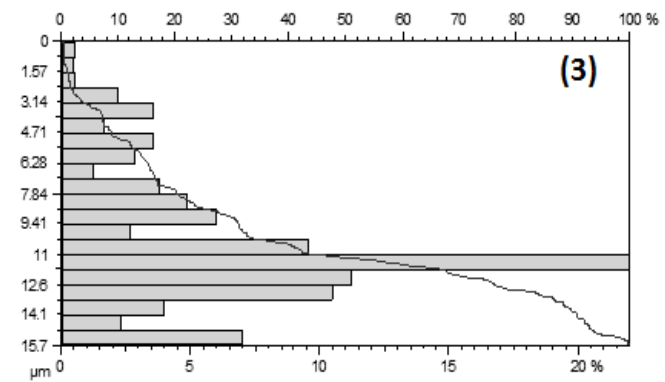

Fig.2. The Abbott curve (bearing area curve) of $\mathrm{Ni}_{61} \mathrm{Cr}_{26} \mathrm{Mo}_{11} \mathrm{Si}_{1,5}$ casting alloy with respect to different melting/casting methods: a) oxy - acetylene burner; b) induction furnace; c) Volta arc 
As follows from the Abbott curve the Remanium CSe alloy casted/melted in induction furnace should exhibit the highest wear resistance (Fig.2).

As one of the parameters testifying to the mechanical resistance of materials is hardness, it can be assumed that the use of an induction furnace provides the ability to obtain a product with the best mechanical properties. As follows from hardness measurements of the tested dental alloy, the HV is in the range 125 425. The highest HV value were obtained for Remanium CSe alloy casted/melted in induction furnace (2).

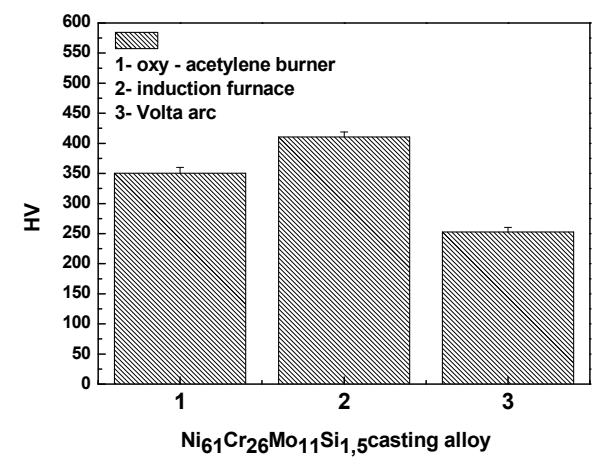

Fig.3. The hardness (HV) comparison of the $\mathrm{Ni}_{61} \mathrm{Cr}_{26} \mathrm{Mo1}_{11} \mathrm{Si}_{1,5}$ casting alloy with respect to different meltSource: own study ing/casting methods

\section{Summary and conclusions}

Technology of metal melting/casting has a significant effect on the surface roughness which is closely associated with metals wettability and colonization of the material by bacteria. All tested samples exhibit a satisfactory surface roughness (Ra below $200 \mathrm{~nm}$ ) with varying degrees of surface area which may determine the final machining. A suitable method allows for finishing the surface of a material with high quality parameters. Materials using arc Volts require chemical methods or electrochemical polishing and for the materials obtained in an induction furnace mechanical grinding may be sufficient.

\section{Literature}

1. BOLLEN CM., LAMBRECHTS P., QUIRYNEN M.1997. Comparison of surface roughness of oral hard materials to the threshold surface roughness for bacterial plaque retention: a review of the literature. Dent Mater 13 (4) 258-269.
2. DELIGIANNI D., KATSALA N., LADAS S., SOTIROPOULOU D., AMEDEE J., MISSIRLIS Y.F.2001. Effect of surface rough- ness of the titanium alloy Ti-6Al-4V on human bone marrow cell response and on protein adsorption. Biomaterials 22, 12411251.

3. HILTBERT L.R., BAGGE-RAVN D., KOLD J., GRAM L.2003. Infuence of surface roughness of stainless steel on microbial adhesion and corrosion resistance. Int. Biodeter. Biodegr. 52, 175-185.

4. KAWAI K., URANO M., EBISU S.2000. Effect of surface roughness of porcelan on adhezion of bacteria and their synthe- sis glucans. J. Prosthet. Dent. 83, 664-667.

5. KLIMECKA-TATAR D., RADOMSKA K., PAWŁOWSKA G.2015. Corrosion resistance, roughness and structure of $\mathrm{Co}_{64} \mathrm{Cr}_{28} \mathrm{Mo}_{5}(\mathrm{Fe}, \mathrm{Si}, \mathrm{Al}, \mathrm{Be})_{3}$ and $\mathrm{Co}_{63} \mathrm{Cr}_{29} \mathrm{Mo}_{6,5}(\mathrm{C}, \mathrm{Si}, \mathrm{Fe}, \mathrm{Mn})_{1,5}$. Jurnal of the Balkan Tribological Association, 1Vol.21, s.204-210.

6. KLIMECKA-TATAR D., RADOMSKA K., JAGIELSKA-WIADEREK K.2014. Wptyw sposobu topienia/odlewania komercyjnego stopu Ni-Cr-Mo na jego odporność korozyjna w roztworze Ringera, Ochrona przed Korozją, 7.

7. MAJEWSKI S., PRYLIŃSKI M.2013. Materiaty i technologie współczesnej protetyki stomatologicznej, Lublin.

8. MARCINIAK J.2003. Biocybernetyka i inżynieria biomedyczna 2000, tom 4 Biomateriały, rozdział 2 Biomateriały metaliczne, PAN, Warszawa, 62-74.

9. RADOMSKA K.., PAWŁOWSKA G., KLIMECKATATAR D.2015. The corrosion processes effect on surface roughness of bonded magnetic material based on Nd-(Fe.Co)-B powder type. Solid State Phenomena. 1 Vol.227. s.39-42.

10. RADOMSKA K.., PAWŁOWSKA G., KLIMECKATATAR D.2013. The effect of melting/casting method of $\mathrm{Ni}-\mathrm{Cr}-\mathrm{Mo}$ dental alloy on the corrosion resistance in Ringer solution. Ochrona przed Korozją. 11.

11. RADOMSKA K., PAWŁOWSKA G., KLIMECKATATAR D.2015. Wpływ parametrów technologicznych na własciwości materiatów inżynierskich stosowanych $w$ medycynie odtwórczej. Inżynieria StomatologicznaBiomateriały, 09/ 7.

12. RADOMSKA K., PAWŁOWSKA G., KLIMECKATATAR D.2015. Struktura i wtaściwości tribologiczne biomedycznych stopów odlewniczych Co-Cr-Mo. Inżynieria Stomatologiczna- Biomateriały, 09/13.

13. SCHMIDSEDER J. CZELEJ. 2011. Stomatologia estetyczna. Lublin.

14. SZYMAŃSKI W.2008. Badanie biofilmu bakteryjnego na powierzchniach biomateriatów. Praca doktorska, Politechnika Łódzka.

15. TAYLOR R., MARYAN C., VERRRAN J.1998. Retention of oral microorganisms on kobalt-chromium alloy and dental acry - lic resin with different surface finishes. J. Prosthet. Dent. 80, 592-597. 